\title{
Oral manifestations of anemia in HIV/AIDS patients without ARV treatment
}

\author{
Wahyu Hidayat*, Tenny Setiani Dewi*, Rudi Wisaksana** \\ *Department of Oral Medicine Faculty of Dentistry Universitas Padjadjaran \\ **Department of Internal Medicine Faculty of Medicine Universitas Padjadjaran
}

\begin{abstract}
Introduction: Acquired immunodeficiency syndrome (AIDS) is a set of symptoms caused by decreases of the immune system that was infected by human immunodeficiency virus (HIV). Blood disorders often found in patient with HIV and associated with HIV infection. Mostly found disorders is anemia of chronic disease. The prevalence of anemia in HIV/AIDS patients reaches $70 \%$. Oral manifestations of anemia are atrophy of the papillae on tongue, glossodynia, pallor, angular cheilitis, glossitis, aphthous ulcers/erosive lesions, candidiasis, and geographic tongue. There are many publications that uses anemia as indicator to determine the prognosis of HIV infection, thus the description of oral manifestation of anemia in the nonARV HIV/AIDS patients is a necessity. The purpose of this study was to describe the oral manifestation of anemia in the non-ARV HIV/AIDS patients. Methods: The methods used were purposive random sampling. Samples were new HIV/AIDS patients who have not got antiretroviral (ARV) treatment. The study included 40 patients in Teratai Clinic Hasan Sadikin Hospital Bandung. Results: Oral manifestations of anemia were found amongst non-ARV HIV/AIDS patients, which were candidiasis in 37 patients, glossodynia in 28 patients, glossitis in 10 patients, and angular cheilitis in 1 patient. Conclusion: From the study found that oral manifestations of anemia that found in non-ARV HIV/AIDS patients were candidiasis, glossodynia, glossitis, and angular cheilitis. HIV/AIDS patients with anemia needed to treat more intensive for better prognosis and quality of life.
\end{abstract}

Keywords: Anemia, HIV/AIDS, Candidiasis, Glossitis, Glossodynia

P-ISSN 1979-0201, e-ISSN 2549-6212 Available from:http://jurnal.unpad.ac.id/pjd/index

DOI:http://dx.doi.org/10.24198/pjd.vol29no1.11752

Submission: Oct 2017 Publishing: March 2017

\section{INTRODUCTION}

Criteria for anemia according to World Health Organization (WHO) is the hemoglobin level is less than $13 \mathrm{~g} / \mathrm{dl}$ formen and less than $12 \mathrm{~g} / \mathrm{dl}$ forwomen. The oral manifestations of anemia are atrophy of the papillae on tongue, pallor, angular cheilitis, glossodynia, glossitis, candidiasis, aphthous ulcers/erosive lesions, and geographic tongue..$^{1-4}$ Anemia is a hematological disorder that often found in HIV/AIDS patients. Several research used hemoglobin as an indicator for anemia. Previous research stated that the prevalence of anemia in HIV/AIDS patients was approximately $70 \%$. Anemia 
in HIV/AIDS patients can be used as predictor for assessing the progression of HIV infection. ${ }^{5-8}$

Frequently found anemia in HIV/AIDS patients is anemia of chronic disease. Sumantri ${ }^{9}$ stated that the prevalence of anemia of chronic disease in HIV/AIDS patients was approximately $64.5 \%$. The classification of anemia based on the morphology of erythrocytes are microcytic anemia, normocytic anemia and macrocytic anemia. Microcytic anemia can caused by iron deficiency, chronic infection, thalassemia, whilst normocytic can caused by iron deficiency, chronic infection, hemolysis, and endocrine disorder; and macrocytic anemia can caused by deficiency of vitamin B12, hypotiroid, and liver disease. The high prevalence of anemia in HIV/AIDS patients is came with oral manifestations, so a research must be done to describe oral manifestations of anemia in the HIV/AIDS patients who have not got antiretroviral treatment in order to evaluated the systemic condition of the patients. ${ }^{9-11}$

\section{METHODS}

This study was a descriptive study and used purposive random sampling method with research subjects were the new HIV/AIDS patients who have not got antiretroviral (ARV) at Teratai Clinic Hasan Sadikin Hospital Bandung from May to November 2014. All HIV/AIDS patients were diagnosed with anemia diagnosed by an internist through routine blood tests and clinical sign. The patients were examined for the oral manifestations by visual and laboratory test, especially for the candida examination after previously signing informed consent.

\section{RESULTS}

The study was conducted at Teratai Clinic Hasan Sadikin Hospital Bandung, from May to November 2014. The total number of new non-ARV HIV/AIDS patients with anemia was 40 people, consisted of 22 Male and 18 Female.

Table 1 showed the distribution of anemia in non- ARV HIV/AIDS patients, with ranges from mild to severe anemia according to WHO classification. From Table 1 showed that mostly, anemia suffered was moderate anemia.
Table 1. Hb description from the patients

\begin{tabular}{cccccc}
\hline No & Name & $\mathrm{N}$ & Averages & Median & Intervals \\
\hline 1 & $\mathrm{Hb}$ & 40 & 10.4 & 10.3 & $8.4-12.1$ \\
2 & Male & 22 & 10.4 & 10.4 & $8.4-12.1$ \\
3 & Female & 18 & 9.8 & 10.3 & $9.0-11.1$ \\
\hline
\end{tabular}

Table 2. Distribution of oral manifestation of anemia

\begin{tabular}{|c|c|c|c|}
\hline No & Oral manifestation & $\mathbf{N}$ & Total \\
\hline 1 & $\begin{array}{l}\text { domembranous candid } \\
\text { A. Found } \\
\text { B. Not found }\end{array}$ & $\begin{array}{c}38 \\
2\end{array}$ & 40 \\
\hline 2 & $\begin{array}{l}\text { dar Cheilitis } \\
\text { A. Found } \\
\text { B. Not found }\end{array}$ & $\begin{array}{c}1 \\
39\end{array}$ & 40 \\
\hline 3 & $\begin{array}{l}\text { graphic tongue } \\
\text { A. Found } \\
\text { B. Not found }\end{array}$ & $\begin{array}{c}3 \\
37\end{array}$ & 40 \\
\hline 4 & $\begin{array}{ll}\text { sitis } & \\
\text { A. Found } \\
\text { B. Not found }\end{array}$ & $\begin{array}{l}10 \\
30\end{array}$ & 40 \\
\hline 5 & $\begin{array}{l}\text { ous ulcers } \\
\text { A. Found } \\
\text { B. Not found }\end{array}$ & $\begin{array}{c}3 \\
37\end{array}$ & 40 \\
\hline 6 & $\begin{array}{l}\text { sodynia } \\
\text { A. Found } \\
\text { B. Not found }\end{array}$ & $\begin{array}{l}28 \\
12\end{array}$ & 40 \\
\hline 7 & $\begin{array}{ll}\text { A. } & \text { Found } \\
\text { B. } & \text { Not found }\end{array}$ & $\begin{array}{c}32 \\
8\end{array}$ & 40 \\
\hline 8 & $\begin{array}{l}\text { ive lesions } \\
\text { A. } \quad \text { Found } \\
\text { B. } \quad \text { Not found }\end{array}$ & $\begin{array}{c}7 \\
33\end{array}$ & 40 \\
\hline
\end{tabular}

After non-ARV HIV/AIDS patients diagnosed with anemia by an internist through routine blood tests, patients who has been signing informed consent were undergoing oral examination to determined the presence anemia oral lesions.

Table 2 showed that the oral manifestations of anemia mostly found were pseudomembranous candidiasis and least found were angular cheilitis.

\section{DISCUSSION}

HIV/AIDS patients will experience immunosuppression along with the HIV serial passage. Following initial infection, people with HIV/AIDS a person may not notice any symptoms, after second stage usually symptomatic symptoms will begin to appear. If it has reached the stage of AIDS, then the opportunistic infection will begin to manifest due to the failure of body's defense. 
Before undergoing treatment, the new HIV/AIDS patients will going through a lot of laboratory tests, include routine blood tests to determine the hematologic condition, because many research reported that the hematologic disorders were often found at people with HIV/AIDS, such as anemia, neutropenia, and thrombocytopenia. The condition of anemia in HIV/AIDS patients can lead to decreasing quality of life and accelerating the serial passage of the virus. ${ }^{5,12,13}$

From this study found that there were 40 non-ARV HIV/AIDS patients with anemia of chronic disease. Sumantri ${ }^{9}$ stated that anemia in HIV/AIDS patients mostly was anemia of chronic disease. It was based on the process of adaptation or body's response towards the occurrence of disorder/ infection. Table 1 showed the distribution of anemia in HIV/AIDS patients and the average of anemia severity found was from mild to moderate.

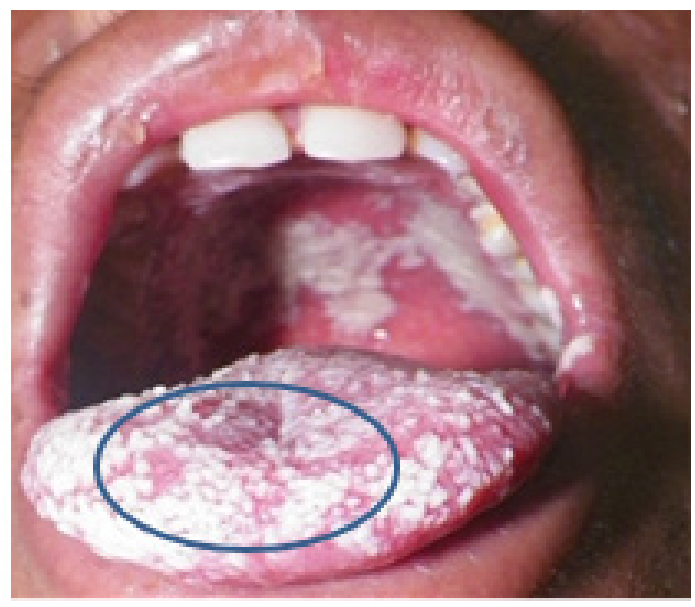

Figure 1. Oral candidiasis

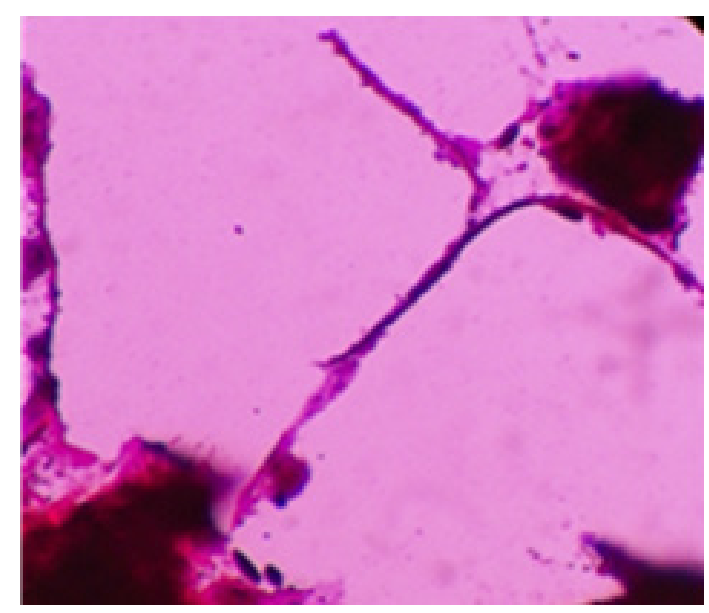

Figure 2. The result of oral swab from the patients
This was the same result with the research conducted by Zarychanski ${ }^{15}$ which stated that in the anemia of chronic disease most severity found was mild or moderate anemia. $8,9,14,15$

Table 2 showed that the distribution of anemia oral lesions in non-ARV HIV/AIDS patients. Mostly found oral manifestations was pseudomembranous candidiasis. Anemia and candidiasis are interconnected. Adeyemo ${ }^{16}$ incorporated anemia as one of the etiology of candidiasis. Anemia in non-ARV HIV/AIDS patients can become the etiology or exacerbating candidiasis due to immunosuppression. . $^{3,16,17}$

Adeyemo $^{16}$ reported that approximately 94\% prevalence of candidiasis can be found in people with HIV, this was the same condition as shown in Table 2, which described the quantity of patients who experienced candidiasis (Fig. 1). WHO classified oral candidiasis as a lesion closely related to HIV infection. Examination of anemia oral lesions in this study was done not only through clinical approach but also through laboratory test by examined candida and routine blood test. Samples which clinically diagnosed with candidiasis was then examined by using $\mathrm{KOH}$ for supporting diagnose (Fig. 2). ${ }^{1,3,16}$

Angular cheilitis, geographic tongue, glossitis, glossodynia, and aphthous ulcers/erosive lesions were oral manifestations of anemia which also found in HIV/AIDS patients, even though there were found not as much as pseudomembranous candidiasis. These oral lesions might becom indicator for dentist and physician that the patient was having anemia, and must get proper and intensive treatment immediately. Anemia could accelerate the HIV serial passage, which will decreases the immune system and quality of life of patients, and finally increases the risk of death. $9,12,14$

\section{CONCLUSION}

Oral manifestations of anemia that found in HIV/ AIDS patients were oral candidiasis, glossodynia, glossitis, and angular cheilitis. All of these lesions can becoming an indicator for dentists and physicians to perform further laboratory tests, in order to give more appropriate treatment that will improve the quality of life of HIV/AIDS patients. 


\section{REFERENCES}

1. Scully C. Medical problems in dentistry. $6^{\text {th }}$ ed. Philadelphia: Churchill Livingstone Elsevier; 2010. p. 177-200.

2. Greenberg Martin MG. Burket's oral medicine oral diagnostic and treatment. $10^{\text {th }}$ ed. BC Decker Inc; 2008. p. 429.

3. Adeyemo TA, Adeyemo WL, Adediran A, Akinbami AJA, Akanmu AS. Orofacial manifestation of hematological disorders: hemato-oncologic and immuno-deficiency disorders. Indian J Dent Res 2011;22(5):688-97.

4. Sambandan T. Review on oral manifestations of blood diseases. J Indian Acad Dent Spec 2010;41(4):41-3.

5. Omoregie R, Omokaro EU, Palmer O, Ogefere HO, Egbeobauwaye A. Prevalence of anaemia among HIV-infected patients in Benin City, Nigeria. Tanzania J Health Res 2009;11(1):1-4

6. Semba RD, Shah N, Vlahov D. Risk factors and cumulative incidence of anaemia among HIVinfected injection drug users. International $J$ STD \& AIDS 2002 Feb;13(2):119-23.

7. Dikshit B, Wanchu A, Sachdeva RK, Sharma A, Das R. Profile of hematological abnormalities of Indian HIV Infected Individuals. BMC Blood Disorders 2009;6:6-11.

8. Akinbami A, Oshinaike 0 , Adeyemo T, Adediran A. Infectious diseases: research and treatment hematologic abnormalities in treatment-naïve HIV patients. Infectious disease: Research and Treatment 2010;3:45-9.

9. Sumantri R, Wisaksana R. Anemia pada penderita HIV/AIDS. Jounal Penyakit Dalam 2009;10(Sep):180-5.

10. Tkachuk D, Hirschmann JV. Wintrobe's atlas of clinical hematology. Toronto: Lippincot Williams and Wilkins; 2007. p. 1-80

11. Chulilla JAM, Colás MSR, Martín MG. Classification of anemia for gastroenterologists. World J Gastroenterol 2009 Oct 7;15(37):4627-37.

12. Claster S. Biology of anemia, differential diagnosis, and treatment options in human immunodeficiency virus infection. J Infectious Disease 2002;185:105-9.

13. Scully C, Flint SF, Porter SR, Moos K. Oral medicine and pathology at a glance. London: Blackwell Pub Ltd; 2010. p. 36-66.

14. Wisaksana R, Sumantri R, Indrati AR, Zwitser $A$, Jusuf $H$, Mast $Q D$, et al. Anemia and iron homeostasis in a cohort of HIV- infected patients in Indonesia. J BMC Infect Dis 2011;11-4.

15. Zarychanski R, Houston DS. Anemia of chronic disease: a harmful disorder or an adaptive, beneficial response? Can Medical Assoc J 2008 Aug 12;179(4):333-7.

16. Adeyemo TA, Adeyemo WL, Adediran A, Akinbami AJA, Akanmu AS. Orofacial manifestations of hematological disorders: Anemia and hemostatic disorders. Indian J Dent Res 2011;22(3):688-97.

17. Tarçın BG. Oral candidosis: aetiology, clinical manifestations, diagnosis and management. $\mathrm{J}$ Marmara University Institute of Health Science 2011;1(2):140-8. 